\title{
Ceftriaxone Reduces Contractility of Isolated Uterine Smooth Muscles of Pregnant and Non-Pregnant Rat
}

\author{
Mossad Elsayed, Ashraf Elkomy and Mohamed Hafez Aboubakr \\ Department of Pharmacology, Faculty of Veterinary Medicine, \\ Benha University, P.O. Box 13736, Moshtohor, Toukh, Qalioubeya, Egypt
}

\begin{abstract}
The effects of ceftriaxone on isolated non-pregnant and pregnant rat uterus have been investigated. The isolated uterine horns were mounted into organ bath containing De Jalon's solution connected to an oscillograph with an isotonic transducer to measure the contractions. Ceftriaxone was injected into the organ bath to study the pharmacological effects on the uterine smooth muscles. Trials were performed to locate the site of action of ceftriaxone on rat's uterus and the obtained results revealed that ceftriaxone had a depressant effect on rats at various stages of sex cycle. It had a direct myometrial depressant effect since, presence of acetylcholine in a small concentration $\left(0.25 \mu \mathrm{g} \mathrm{mL} \mathrm{m}^{-1}\right.$ bath) produced its stimulatory effect in the presence of ceftriaxone $256 \mu \mathrm{g} \mathrm{mL}^{-1}$ bath and $256 \mu \mathrm{g} \mathrm{mL} \mathrm{m}^{-1}$ bath of ceftriaxone relaxed the uterus after its stimulation with propranolol $1 \mu \mathrm{g} \mathrm{mL} \mathrm{m}^{-1}$ bath.
\end{abstract}

Key words: Ceftriaxone, isolated, uterus, pregnancy, rat, oscillograph, Egypt

\section{INTRODUCTION}

Ceftriaxone is a broad spectrum cephalosporin resistant to various types of $\beta$-lactamases with potent activity against gram-positive and negative bacteria including Enterobacteriaceae, Haemophilus influenzae, Streptococcus pneumoniae and other Nonenterococcal streptococci, Methicillin-resistant staphylococci, Enterococci, Pseudomonas aeruginosa and Bacteroides fragilis were typically resistant (Neu et al., 1981). The drug acts through inhibition of transpeptidase enzymes responsible for the final step in bacterial cell wall synthesis (Waxam and Strominger, 1982) and has broad stability against beta-hydrolysis ( $\mathrm{Neu}, 1985$ ). In human medicine, ceftriaxone is widely used because of its prolonged terminal half-life (5.4-8.2 h) that allows its prescription on a single administration per day basis (Patel et al., 1982; Meyers et al., 1983; Ti et al., 1984; Zhou et al., 1985; Bourget et al., 1993). So, expanded informations concerning the pharmacodynamic effects of ceftriaxone will be of benefits to physicians and their patients. The present study was aimed to study pharmacodynamic aspects of ceftriaxone on isolated uterine smooth muscles.

\section{MATERIALS AND METHODS}

Drug: Ceftriaxone is a sterile, semisynthetic, broadspectrum 3rd generation cephalosporin antibiotic for intravenous or intramuscular administration. Ceftriaxone is a white to yellowish-orange crystalline powder which is readily soluble in water, sparingly soluble in methanol and very slightly soluble in ethanol. The $\mathrm{pH}$ of a $1 \%$ aqueous solution is approximately 6.7. It was produced by Smithkline Beecham for Novartis Pharma Company (Egypt) and has the commercial name Ceftriaxone ${ }^{\circledR}$.

Perfusion fluids for pharmacological experiments De Jalon's solution:

Sodium chloride

Potassium chloride

Calcium chloride

Glucose

Sodium bicarbonate

Distilled water

$0.50 \mathrm{~g}$ $1000 \mathrm{~mL}$

The above mentioned physiological salt solutions were prepared as indicated by Staff members (University of Edinburgh, Department of Pharmacology, 1970).

Chemicals: Acetylcholine chloride (Hoffman-La Roche Company, France). Propranol hydrochrolide (Inderal®, I.C.I, Macclesfield, England).

\section{Devices}

Glass jar bath: A glass water bath of about $750 \mathrm{~mL}$ capacity fitted into a metal stand in which a movableelectric heater was located to maintain the temperature as requied. An inner glass tube (organ bath) of $40 \mathrm{~mL}$ capacity passed through the bottom of the stand and was connected by a T-shaped glass tube.

Corresponding Author: Mohamed Hafez Aboubakr, Department of Pharmacology, Faculty of Veterinary Medicine, Benha University, P.O. Box 13736, Moshtohor, Toukh, Qalioubeya, Egypt 
Harvard universal oscillographe and transducers: Two channels curvilinear oscillograph (Harvard U.K) with an isotonic transducer (Harvard App. Ltd.) which was employed for recording the effect of ceftriaxone on isolated tissues.

Preparation of rat's uterine smooth muscle: The method described by staff members (University of Edinburgh, Department of Pharmacology, 1970) was used for studying the effect of ceftriaxone on uterine muscle of rats at various stages of sex cycle. In this respect, mature female rats at various stages of sex cycle (estrus, non-estrus, early pregnant and late pregnant) were used where vaginal smear was performed for determination of the stage of sex cycle of the animals (Sharaf, 1954). Animals after being examined were killed, their uteri were dissected out and one uterine horn was suspended in the organ bath containing warm oxygenated De Jalon's solution at $32^{\circ} \mathrm{C}$ from the bottom end by tying to a glass hook and the top end was tied by a thread to an isotonic transducer using cotton thread. The transducer was coupled to an amplifier driving a direct writing Harvard universal oscillograph. The speed was adjusted to be $0.25 \mathrm{~mm} \mathrm{sec}^{-1}$.

The tissues were subjected to a resting tension of $1.0 \mathrm{~g}$, the strips were allowed to equilibrate for approximately $30 \mathrm{~min}$ by the change of bath solution every $15 \mathrm{~min}$ after that the normal uterine motility was recorded and the effects of graded increased concentrations of ceftriaxone was demonstrated. The site of action of ceftriaxone was also investigated.

\section{RESULTS AND DISCUSSION}

The effect of ceftriaxone on isolated rat's uterus were shown in Table 1. The effect of ceftriaxone on isolated rat's uterus at various stages of sex cycle were shown in Fig. 1a-d. Trials were performed to locate the site of action

Table 1: Effect of ceftriaxone on uterine motility of rats at various stages of sex cycle Response of uterine motility

\begin{tabular}{|c|c|c|c|c|}
\hline Concentrations ( $\mu \mathrm{g} \mathrm{mL} \mathrm{m}^{-1}$ bath) & Non-estrus & Estrus & Early pregnant & Late pregnant \\
\hline 32 & No effect & No effect & No effect & No effect \\
\hline 64 & $\begin{array}{l}\text { Slight inhibition in the } \\
\text { force and frequency }\end{array}$ & $\begin{array}{l}\text { Slight inhibition } \\
\text { in the force and frequency }\end{array}$ & $\begin{array}{l}\text { Slight inhibition } \\
\text { in the force and frequency }\end{array}$ & No effect \\
\hline 128 & $\begin{array}{l}\text { Slight inhibition in the } \\
\text { force and frequency }\end{array}$ & $\begin{array}{l}\text { Marked inhibition } \\
\text { in the force and frequency }\end{array}$ & $\begin{array}{l}\text { Marked inhibition } \\
\text { in the force and frequency }\end{array}$ & $\begin{array}{l}\text { Moderate inhibition } \\
\text { in the force and frequency }\end{array}$ \\
\hline 256 & Complete relaxation & Complete relaxation & Complete relaxation & Complete relaxation \\
\hline
\end{tabular}
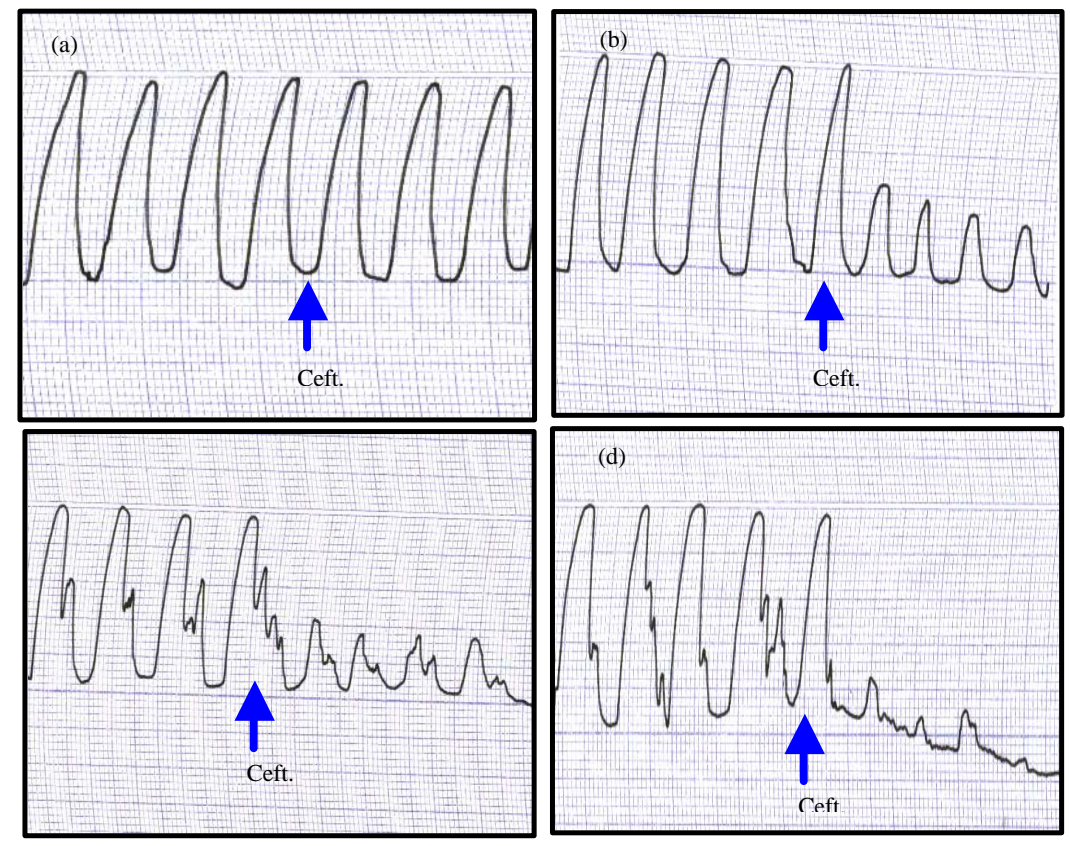

Fig. 1: Effect of ceftriaxone (Ceft.) on isolated rat's uterus: a) $32 \mu \mathrm{g} \mathrm{mL} \mathrm{m}^{-1}$ bath ceftriaxone (Ceft.) in non-estrus stage; b) $64 \mu \mathrm{g} \mathrm{mL} \mathrm{mL}^{-1}$ bath ceftriaxone (Ceft.) in estrus stage; c) $128 \mu \mathrm{g} \mathrm{mL} \mathrm{m}^{-1}$ bath ceftriaxone (Ceft.) in early pregnancy stage and d) $256 \mu \mathrm{g} \mathrm{mL} \mathrm{m}^{-1}$ bath ceftriaxone (Ceft.) in late pregnany stage 


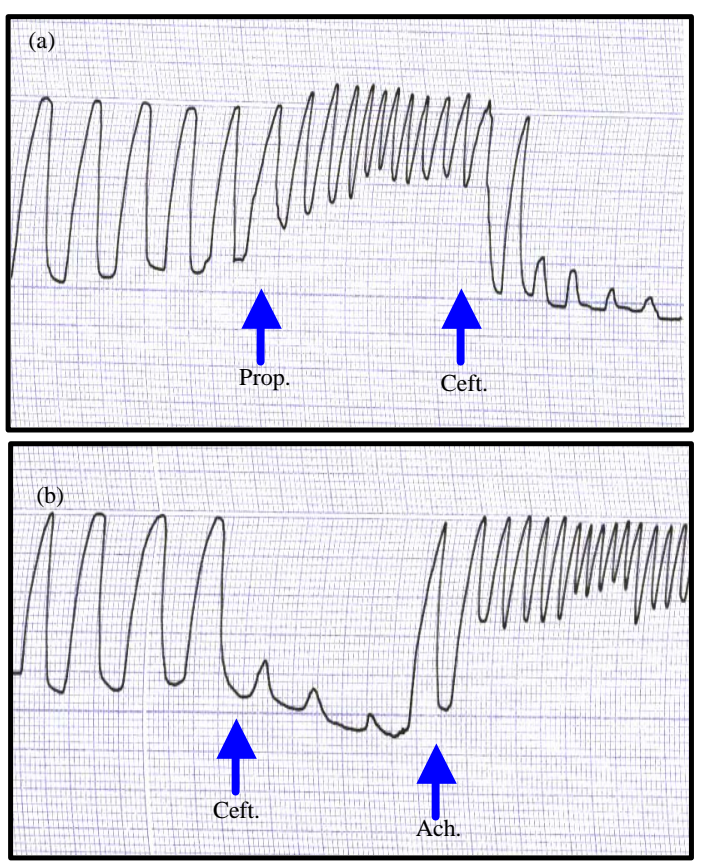

Fig. 2: Site of action of ceftriaxone (Ceft.) on isolated rat's uterus during estrus stage: a) $1 \mu \mathrm{g} \mathrm{mL} \mathrm{m}^{-1}$ bath propranolol (Prop.) followed by $256 \mu \mathrm{g} \mathrm{mL} \mathrm{m}^{-1}$ bath ceftriaxone (Ceft.) and b) $256 \mu \mathrm{g} \mathrm{mL} \mathrm{m}^{-1}$ bath ceftriaxone (Ceft.) followed by $0.25 \mu \mathrm{g} \mathrm{mL} \mathrm{m}^{-1}$ bath acetylcholine (Ach.)

of ceftriaxone on rat's uterus and the obtained results revealed that ceftriaxone had a depressant effect on rats at various stages of sex cycle. It had a direct myometrial depressant effect since presence of acetylcholine in a small concentration $\left(0.25 \mu \mathrm{g} \mathrm{mL} \mathrm{m}^{-1}\right.$ bath) produced its stimulatory effect in the presence of ceftriaxone $256 \mu \mathrm{g} \mathrm{mL}^{-1}$ bath and $256 \mu \mathrm{g} \mathrm{mL}^{-1}$ bath of ceftriaxone relaxed the uterus after its stimulation with propranolol $1 \mu \mathrm{g} \mathrm{mL}{ }^{-1}$ bath.

The site of action of ceftriaxone on isolated rat's uterus during estrus stage was shown in Fig. 2a, b. The present investigation showed that ceftriaxone in vitro inhibited the contractility of rat's uterus during non-pregnant stages (estrus and non-estrus) and during pregnant stages (early and late pregnancy). The effect was dose dependant.

These effects might be attributed to the direct action of the ceftriaxone on the isolated uterus. During the non- pregnant and pregnant stages, the addition of acetylcholine in a small concentration $\left(0.25 \mu \mathrm{g} \mathrm{mL}^{-1}\right.$ bath) produced its stimulatory effect in the presence of ceftriaxone $\left(256 \mu \mathrm{g} \mathrm{mL}^{-1}\right.$ bath) and the ceftriaxone in the same concentration, relaxed the uterus after its stimulation with $1 \mu \mathrm{g}$ propranolol $\mathrm{mL}^{-1}$ bath. The obtained results were consistent with those recorded by Takai et al. (1980) who found that cefeperazone depressed the uterine motility in two of six experiments while during pregnancy they found that cefoperazone might not affected or depressed and/or stimulated the uterine motility. In other observation, Kai et al. (1992) recorded that cefepime had no effect on the delivery status of the offspring rats and Takai et al. (1982) who found that the spontaneous movement and tone of isolated uterus were not affected following cefbuperazone application. The obtained results during estrus and non-estrus stages were not consistent with those obtained by El-Sayed et al. (1997) who recorded that concentrations of 2048 and $4096 \mu \mathrm{g}$ cefamandole $\mathrm{mL}^{-1}$ bath caused marked stimulation in force and frequency of rat uterine muscle in all stages of sex cycle. These differences were explained by Jankovic et al. (1996) who proved that effects of $\beta$-lactam antibiotics on smooth muscle isolated preparations were tissue and species dependent indicating selectivity of their action.

\section{CONCLUSION}

These findings indicated that ceftriaxone had a direct depressant effect on isolated uterine smooth muscles.

\section{REFERENCES}

Bourget, P., H. Fernandez, V. Quinquis and C. Delouis, 1993. Pharmacokinetics and protein binding of ceftriaxone during pregnancy. Antibiotic Agents Chemother., 37: 54-59.

El-Sayed, M.G., M.R. Hassanin, M.H. Hafez, A.A. ElKomy and A. Mohamed, 1997. Some pharmacodynamic and biochemical aspects of cefamandole. Dtsch. Tierarztl. Wochenschr., 104: 481-487.

Jankovic, S.M., D. Kouvelas and M. Mitrovic, 1996. Spasmogenic action of â-lactam antibiotics on the gastrointestinal tract of experimental animals. Indian J. Med. Res., 104: 216-222.

Kai, S., H. Kohmura, K. Ishikawa, S. Kawano and A. Sakaiet al., 1992. Reproductive and developmental toxicity studies on cefepime dihydrochloride administered subcutaneously to rats during the premating, gestation and lactation periods. Jpn. J. Antibiot., 45: 642-660.

Meyers, B.R., E.S. Srulevitch, J. Jacobson and S.Z. Hirschman, 1983. Crossover study of the pharmacokinetics of ceftriaxone administered intravenously or intramuscularly to healthy volunteers. Antibiotic Agents Chemother., 24: $812-814$. 
Neu, H.C., 1985. Relation of structural properties of betalactam antibiotics to antibacterial activity. Am. J. Med., 79: 2-13.

Neu, H.C., N.J. Meropol and K.P. Fu, 1981. Antibacterial activity of ceftriaxone (Ro 13-9904), a beta-lactamasestable cephalosporin. Antimicro. Agents Chemother., 19: 414-423.

Patel, I.H., R.E. Weinfeld, J. Konikoff and M. Parsonnet, 1982. Pharmacokinetics and tolerance of ceftriaxone in humans after single-dose intramuscular administration in water and lidocaine diluents. Antibiotic Agents Chemother., 21: 957-962.

Sharaf, A.A., 1954. Mechanism of hormone antagonism. Ph.D. Thesis, University of London.

Takai, A., S. Hirai, I. Watanabe, T. Hiraiwa and N. Abe et al., 1980. General pharmacology of cefoperazone, a new cephalosporin antibiotic (author's transl). Jpn. J. Antibiot., 33: 994-1018.
Takai, A., S. Hirai, I. Watanabe, T. Hiraiwa and N. Abe et al., 1982. General pharmacology of T-1982, a new cephamycin antibiotic. Jpn. J. Antibiot., 35: 2139-2154.

Ti, T.Y., L. Fortin, J.H. Kreeft, D.S. East, R.I. Ogilvie and P.J. Somerville, 1984. Kinetic disposition of intravenous ceftriaxone in normal subjects and patients with renal failure on hemodialysis or peritoneal dialysis. Antimicrobial Agents Chemother., 25: 83-87.

University of Edinburgh, Department of Pharmacology, 1970. Pharmacological Experiments on Isolated Preparations. 2nd Edn., Churchill Livingstone, Edinburgh, USA., pp: 163.

Waxam, D.J. and J.L. Strominger, 1982. Chemistry and Biology of Beta-Lactam Antibiotics. Academic Press, New York.

Zhou, H.H., Y.P. Chan, K. Arnold and M. Sun, 1985. Single-dose pharmacokinetics of ceftriaxone in healthy Chinese adults. Antimicrobial Agents Chemother., 27: 192-196. 